\title{
Designing catchment area for water resources management in ITS campus
}

\author{
Joni Hermana ${ }^{*}$, Irhamah $^{2}$, Dian Saptarini ${ }^{3}$ Tatas $^{4}$ \\ ${ }^{1}$ Rector of Institut Teknologi Sepuluh Nopember, Surabaya 60111, Indonesia \\ ${ }^{2}$ Department of Statistics, Institut Teknologi Sepuluh Nopember, Surabaya 60111, Indonesia \\ ${ }^{3}$ Department of Biology, Institut Teknologi Sepuluh Nopember, Surabaya 60111, Indonesia \\ ${ }^{4}$ Departement of Civil Engineering, Institut Teknologi Sepuluh Nopember, Surabaya 60111, Indonesia
}

\begin{abstract}
Institut Teknologi Sepuluh Nopember (ITS) Campus, with the area of $167.4 \mathrm{Ha}$, is located within Surabaya coastal region in the eastern part of Java Island. It has initial characteristic with wetlands and swamps ecosystem. As a science and technological university, with the main acitivities in teaching, experimental laboratory works, and student activities, ITS is, currently, using $\pm 49 \%$ of its total vast area as building blocks for supporting academic facilities. Being a campus in a coastal zone, the commonly main problems are high porous soil, brackish surface water, high level of ground water, an obstructed drainage tendency because of delicate slant, and low catchment capability. This paper provides an action program on how ITS manage water resources within campus area in order to suppress environmental damage. Many steps had been taken into account for water catchment role, for instance: maintaining the catchment area on the main ITS master plan, planning catchment pond, surface water stabilization by preventing ground water usage, interrupting drainage water flow as being directly discharged into the city drainage system, rain water harvesting, and also designing floating floor for buildings.
\end{abstract}

\section{Introduction}

ITS Smart Eco Campus that launched in 2015 is a continuation of the Eco Campus program which began since 2011. ITS Smart Eco Campus is an initiative form from ITS to implement sustainable development program in the campus environment. As an academic society, ITS will utilize technology and science to enable to work in harmony with nature. Therefore, ITS took the initiative to be a pioneer in the development of smart eco campus and utilize every campus element to create environmentally friendly project. Contributions to environmental sustainability programs are the part of the commitments in the Sustainable Development Goals (SDGs).

The implementation for developing ITS Smart Eco Campus is focused in creating an environmentally friendly campus that is embedded with various activities involving students and faculty members. There are five main points of ITS Smart Eco-Campus, namely:

1. Socio Engineering

2. Energy and Water

3. Waste Management

4. Green Area, University Forest and Biodiversity

5. Transportation

ITS is a science and technological university that is located in Surabaya, Indonesia with the effective area of 167.4 Ha. Although ITS had been established as the state university since 1960, however the main ITS buildings campus was built in 1977 and was inaugurated its use in 1982 [1]. In 2017, according to the Ministry of Research,
Technology and Higher Education (Kemristekdikti) Indonesia, ITS is ranked as the $5^{\text {th }}$ best university in Indonesia. In addition, ITS also became one of the 10 Indonesia's flagship university version of QS World University Ranking. In 2017, ITS achieved the UI Green Metric World University Ranking [2].

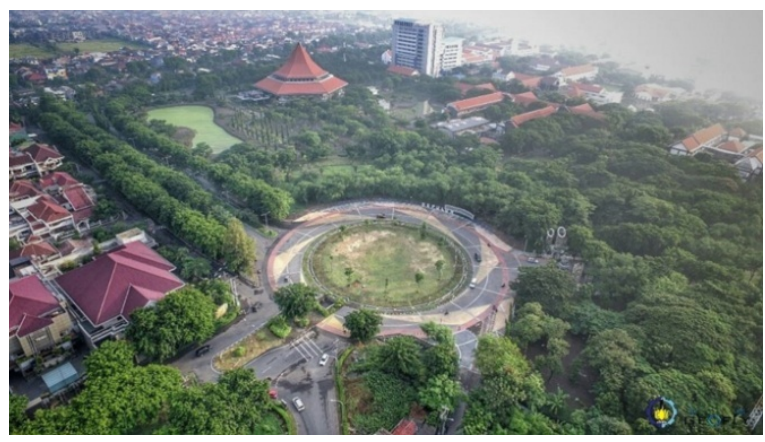

Fig. 1. ITS main campus

Currently, ITS has 38 departments that spread across ten Faculties with 970 lecturers and professors, 1135 supporting staffs and with the total number of 20,000 students, starting from vocational, undergraduate, graduate and doctoral study programs. To support and maintain the water needs for that number of faculty members, operation and maintenance laboratory, academic supporting facilities, student dormitories, including for ITS mosque, the average water demand in ITS reaches $32,627 \mathrm{~m}^{3} /$ month equal to $1,087 \mathrm{~m}^{3} /$ day [2]. 
ITS uses water from the Municipal Water Supply Enterprise (PDAM) Surabaya to meet its domestic needs, because the unconfined aquifer is unlikely to be consumed. The quality of groundwater in unconfined aquifer within the main ITS campus area and its surroundings is: 4.39 - $6.90 \mathrm{ppt}$ salinity, 1.16 - 6.79 $\mathrm{mg} / \mathrm{L}$ nitrate $\left(\mathrm{NO}_{3}\right), 0.18-2.12 \mathrm{mg} / \mathrm{L}$ phosphate $\left(\mathrm{PO}_{4}\right)$, while for nitrite and ammonia is not detected. Although there is a possibility for groundwater consumption, based on its quality, ITS does not conduct exploration or groundwater exploitation on confined aquifer. because the domestic water requirement is still sufficient from the PDAM, Surabaya.

The main campus of ITS is in the Coastal Zone adjacent to the Madura Strait, with the average of slope the land surface between $0-3 \%$ and average elevation around 3-5 $\mathrm{m}$ from the sea level. The nearest distance from the main ITS campus to the coastline area is about $3.6 \mathrm{~km}$ with the geological areal condition is an alluvial sediment [4] which has not been densed until loose, a mixture of sand, silt, clay [3]. These rocks are the result of deposition from the Brantas River system where ITS lies at the downstream from the Brantas Watershed. Indonesia is a tropical region with an average annual rainfall over $1500 \mathrm{~mm}$.

Based on soil conditions, distance to shoreline, average surface slope, average elevation, rainfall potential, it causes various challenges in terms of water resources management. These challenges include, that the main campus of ITS is a region that:

1. Very small water catchment potential, due to coastal areas with low elevation and ground water depth of less than 1 meter.

2. The small slope of the soil causes the drainage flow very slow and supported by very shallow groundwater conditions, the potential for very high inundation

3. The groundwater is relatively brackish, so it can be used for aquaculture brackish water fisheries.

\section{Water conservation implementation}

The form of water conservation program is water storage in ground water tank, elevated reservoir, lake or pond, long storage channel and wet land area conservation. Conservation forms are water recycling used for garden sprinkler system and water efficient appliances (water tap, flush toilet, etc). Beside the water reservoirs, because ITS is a former area of swamp and rice field, the majority of campus building structures are elevated, so that under the structure of the building can still be a recharge area and does not change the coefficient of runoff. Here the pictures of the form of water conservation program implementation.

\subsection{Elevated structures}
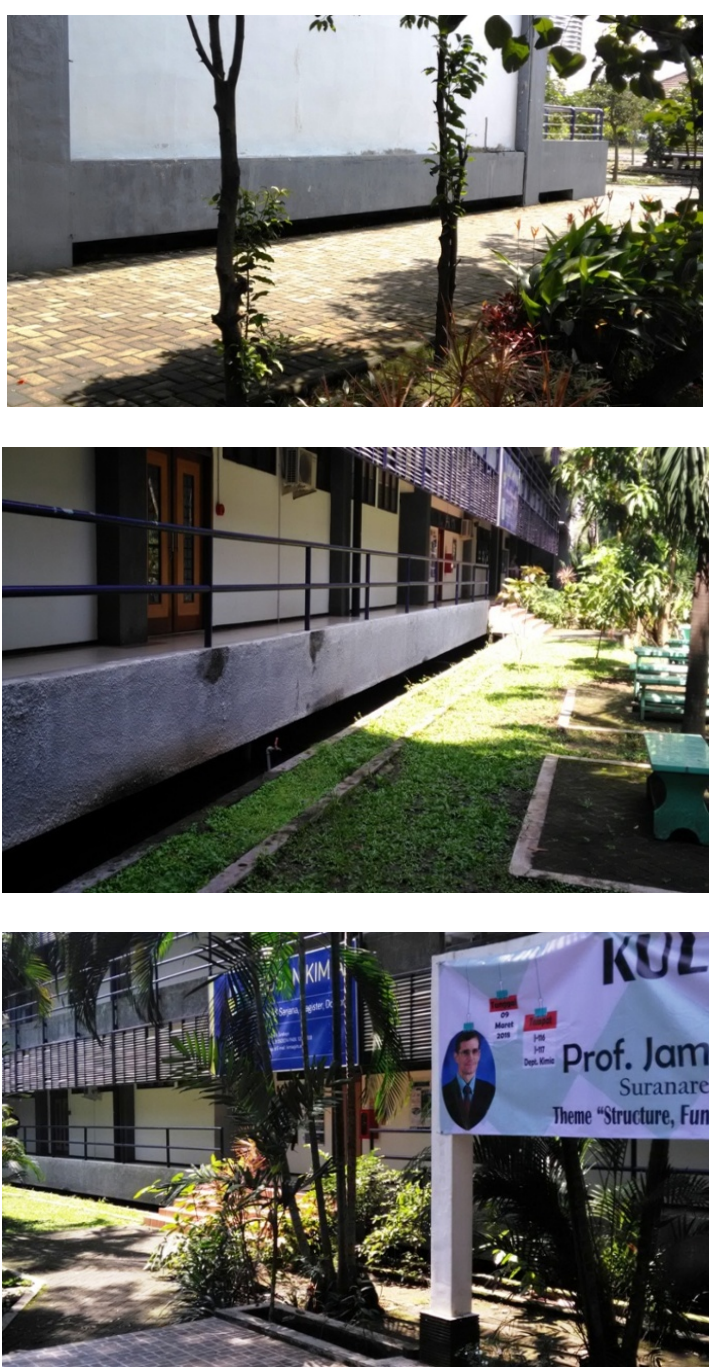

Fig. 2. Floating floor in Geomatics Engineering Dept, Physics Departement and Chemistry Department

\subsection{Underground and elevated tank}

Manarul Ilmi Mosque is the biggest praying center at ITS which requires supply water about 25 to $30 \mathrm{~m}^{3}$ a day. In Friday it increases up to 45 to $50 \mathrm{~m}^{3} /$ day. The water is not only utilized for wudhu or ablution, but also for maintaining the mosque and its garden. In 2013, the mosque installed ground tank as water recycling system from used wudhu waste water. One of these goals is to reduce water consumption from municipal water company. The water recycling system has four chambers that one chamber is used for sedimentation and filtration processes while the others are used as water reservoirs (Fig. 3). Each chamber has capacity of 5,000 Liters with gravity water flow system. Automatic sprinklers from the chambers with pumps are used for daily garden watering specially during the dry season [2]. The wudhu water reuse is not only implemented in the Manarul Ilmi Mosque, but also in Mosque of ITS Manyar Campus. 


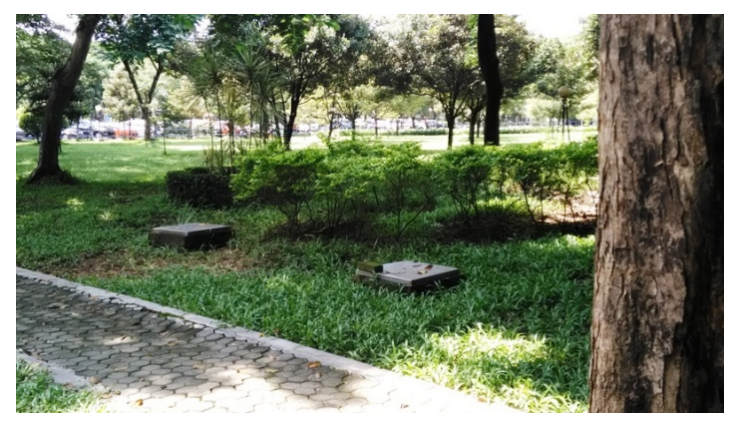

Ablution water circulation

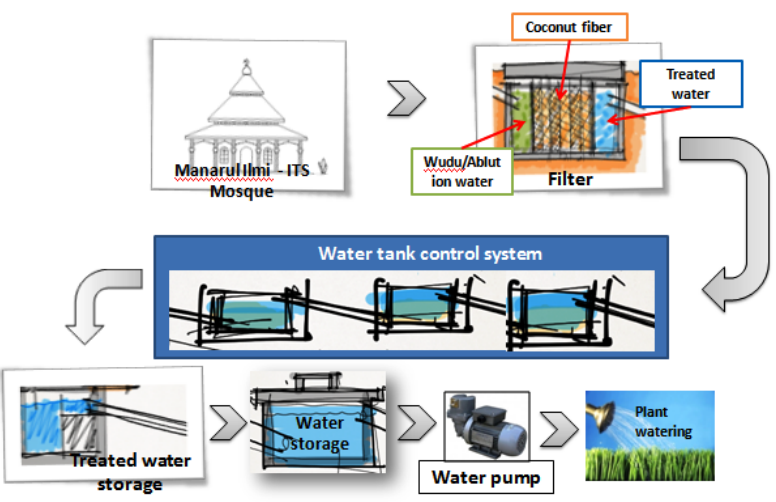

Fig. 3. Underground tank as water recycling system in Manarul Ilmi Mosque

One of the activities in the Smart Eco Campus is developing urban farming by planting some organic vegetables with the trademark SayOr ITS (means literally Sayur Organik or Organic Vegetables of ITS). In addition, it is also developed organic livestock and organic fruits. The ITS development effort of organic vegetables finally noticed by PT Takiron by providing assistance in the form of underground tanks to accommodate the rain water that is used to water the plants (Fig. 4).

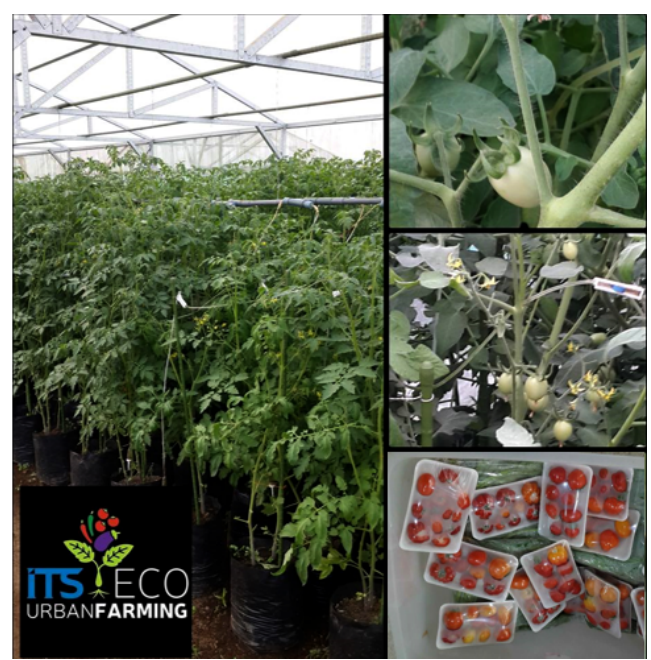

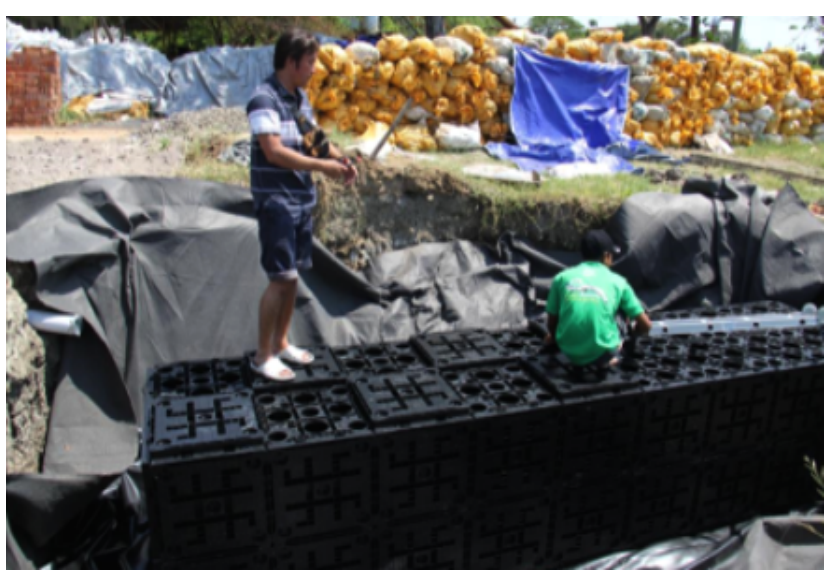

Fig. 4. Urban farming ITS products and underground tanks to harvest rainwater

Besides in the form of underground tank, rain water catchment also uses elevated reservoir. Rainwater is collected through the roof of the building and flowed into the reservoir through pipes.

\subsection{Lake or pond}

The main campus of ITS has several points that become a patch pond. The patch pond serves as a retention pond; there are 10 retention ponds and one detention pond (Table 1). The detention pond is The Graha Sepuluh Nopember Pond, while the others are retention ponds. The capacity of the Graha Sepuluh Nopember pond reaches $18,014.00 \mathrm{~m}^{3}$ equipped with a floodgate that can be flowed to the nearest drainage channel. In total, the artificial pond area in ITS main campus is approximate $49,783.00 \mathrm{~m}^{3}$, with the volume of water at the measurement reaching $31,913.00 \mathrm{~m}^{3}$ or almost $65 \%$ of the capacity. Measurement of pond capacity using bathymetry data as measured using USV Boat made by ITS, Himage USV 1 (Fig. 5 - 6) [5].

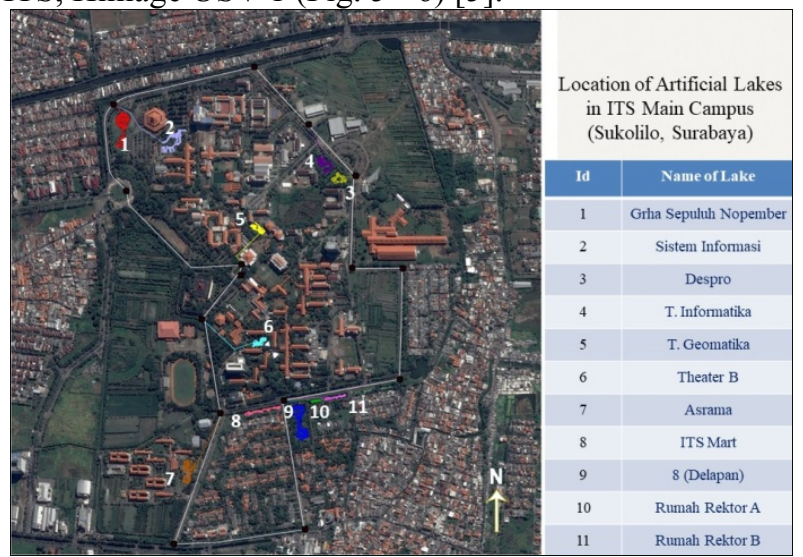

Fig. 5. Location of artificial lake in ITS main campus 

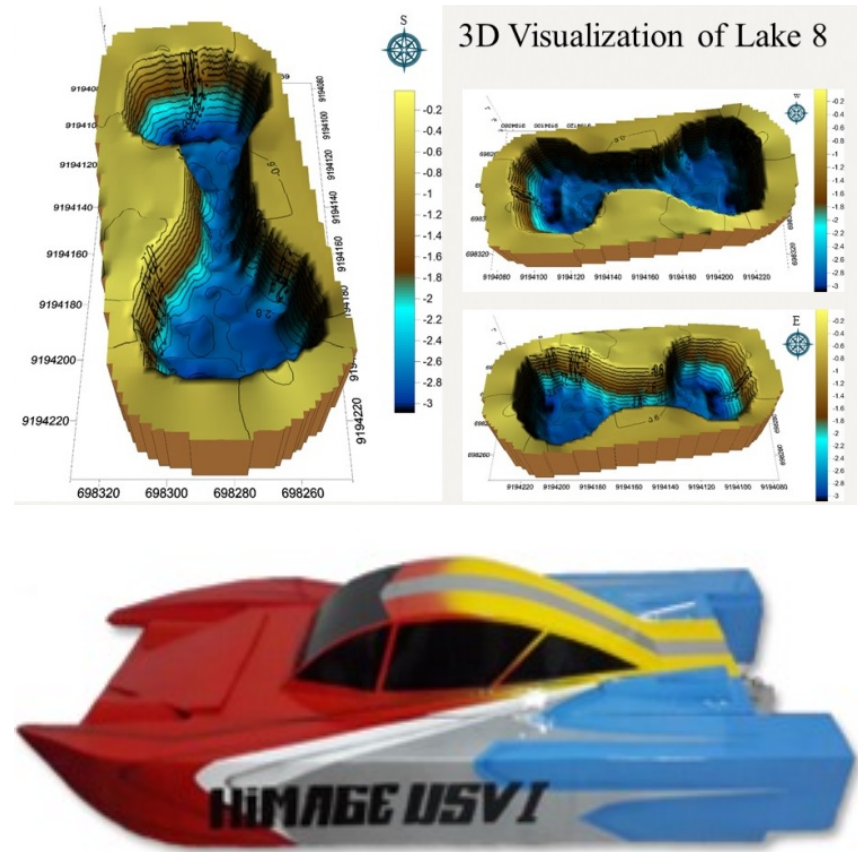

Fig. 6. (a) 3D Visualitation of lake 8 with volume $9695 \mathrm{~m}^{3}$ (b) USV boat as bathymeter, Himage USV 1, made in ITS

Table 1. Artificial lakes in ITS main campus

\begin{tabular}{|c|c|c|c|c|}
\hline Id & Name of Lake & Area $\left(m^{2}\right)$ & $\begin{array}{c}\text { Water } \\
\text { Volume } \\
\left(\mathrm{m}^{3}\right)\end{array}$ & $\begin{array}{c}\text { Pond } \\
\text { Capacity } \\
\left(\mathrm{m}^{3}\right)\end{array}$ \\
\hline 1 & 8 (Delapan) & $4,976.40$ & 6,975 & 9,695 \\
\hline 2 & Rumah Rektor A & 435.97 & 223 & 423 \\
\hline 3 & Rumah Rektor B & 797.43 & 239 & 365 \\
\hline 4 & $\begin{array}{l}\text { Graha Sepuluh } \\
\text { Nopember }\end{array}$ & $4,990.95$ & 11,133 & 18,014 \\
\hline 5 & ITS Mart & $2,168.33$ & 745 & 1,145 \\
\hline 6 & $\begin{array}{l}\text { Student } \\
\text { Dormitory }\end{array}$ & $2,812.09$ & 3,803 & 5,796 \\
\hline 7 & T. Geomatika & $1,065.20$ & 1,378 & 2,248 \\
\hline 8 & $\begin{array}{l}\text { Information } \\
\text { System Dept. }\end{array}$ & $3,586.15$ & 4,217 & 6,168 \\
\hline 9 & Theater B & $1,073.23$ & 1,387 & 2,058 \\
\hline 10 & $\begin{array}{l}\text { Informatics Eng. } \\
\text { Dept. }\end{array}$ & $1,697.51$ & 704 & 2,147 \\
\hline 11 & $\begin{array}{l}\text { Design Product } \\
\text { Dept. }\end{array}$ & $2,514.02$ & 1,109 & 1,724 \\
\hline & $\Sigma$ & $26,117.28$ & 31,913 & $49,783.00$ \\
\hline
\end{tabular}

(Source: Geomatics Department ITS, 2017)

In addition to the pond that mention above, there are still some pond in the department environment with a function as retention pond.
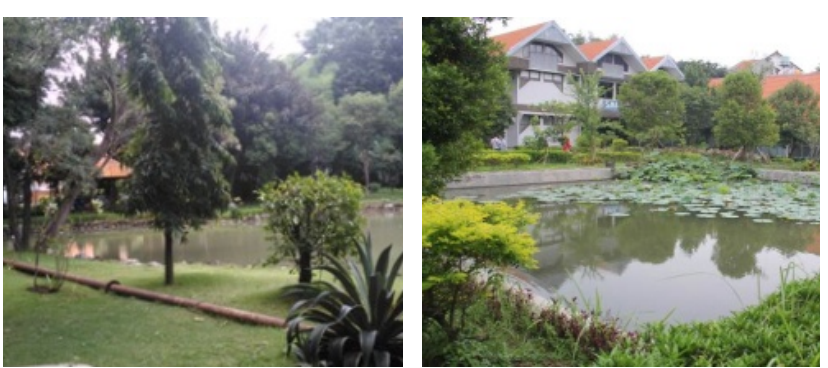

Pond near Physic

Department for fishery pond $2.5 \mathrm{~m}$ depth

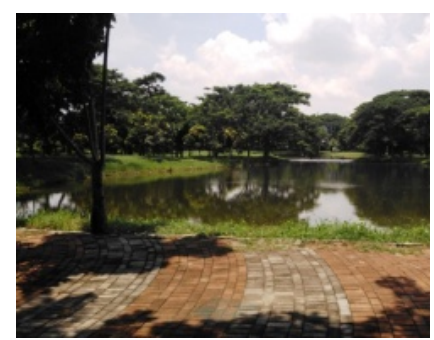

The eight-shaped retention pond which has jogging track for floods control, sport activities and recreation

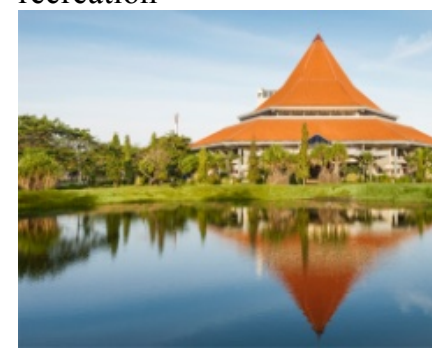

Detention pond in Graha Sepuluh Nopember

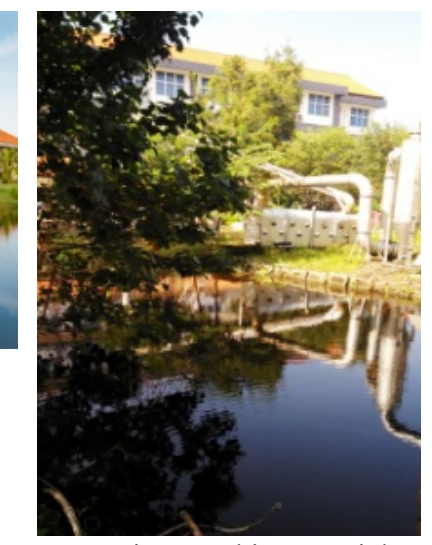

Retention pond in Material and Metalurgy dept.

Fig. 7. Retention and detetion ponds in ITS

\subsection{Wet land area conservation}

ITS also has a wetland area, with a total area around 29.6 ha or about $16 \%$ of the total area of Main Campus of ITS. Those wetland areas are utilized by the surrounding community by growing water vegetables, like water spinach, pandanus. In addition, there are also used as agricultural land. 

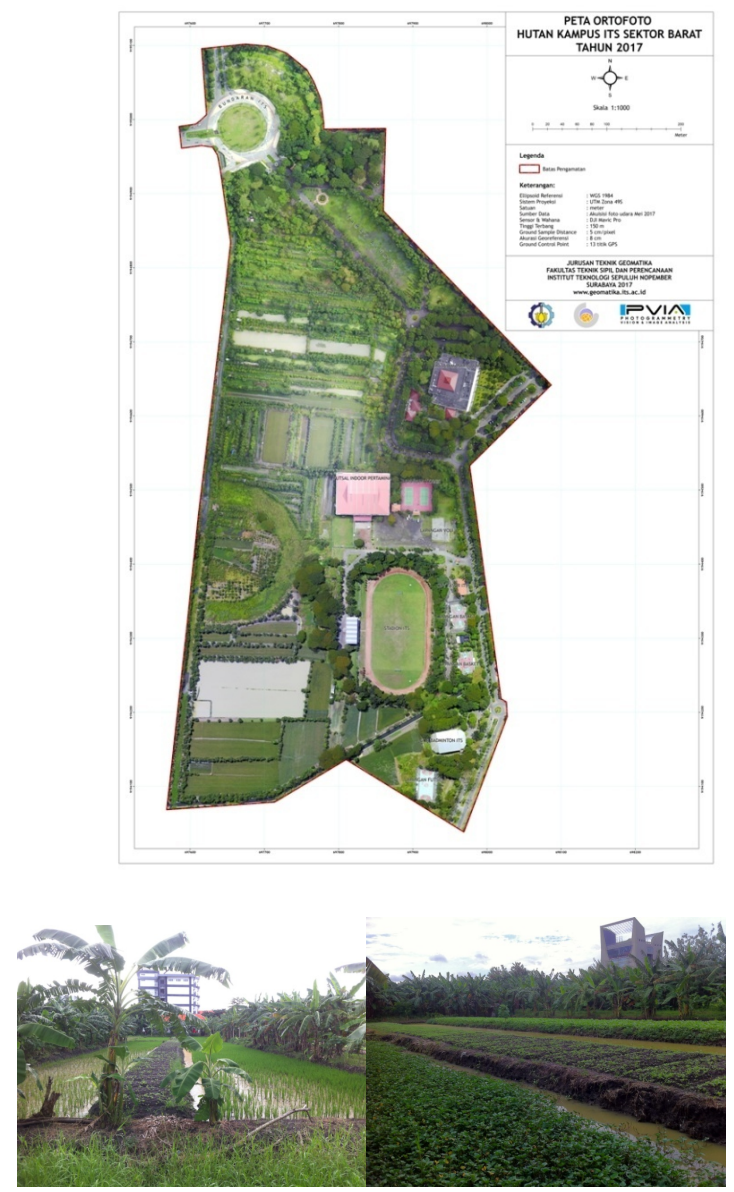

Fig. 8. ITS green openspaces with wetland area

\subsection{Long storage channel}

ITS also has a long storage channel, with a channel length reach 470 meters and a channel width around 6 meters.

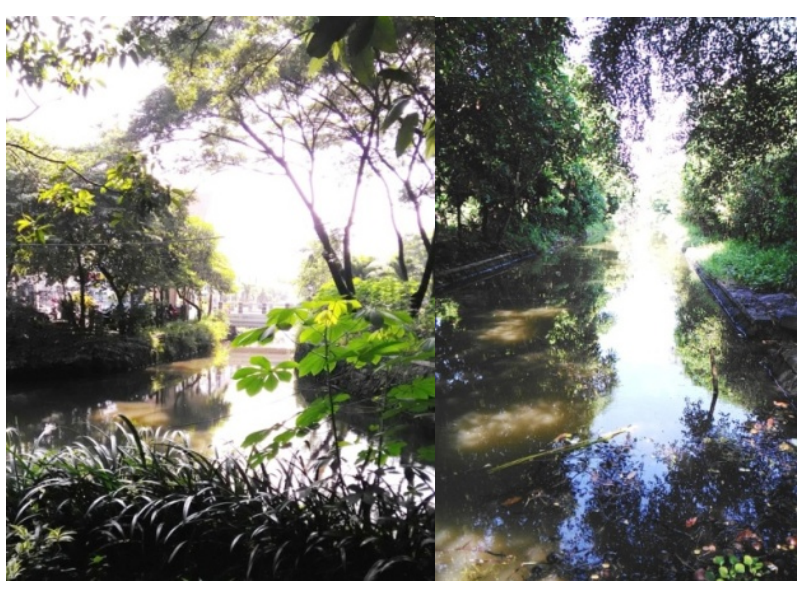

Fig. 9. ITS long storage channel

\section{Summary}

Many programs could be implemented that support sustainable water management within ITS campus, including the stimulation of onsite infiltration of rainfall and runoff, protecting and enhancing surface water quality, promoting ground water recharge, reuse and recycle wastewater, capturing and reuse rain water, and also treating grey water and black water.

\section{References}

1. Utama, W. The Golden ITS. Media Informasi dan Komunikasi ITS, ISBN: 978-979-8897-71-9. Surabaya (2010)

2. Hermana, J., Herumurti, W., and Irhamah. Sustainable Water Management in Tropical Region Campus: Study Case of Institut Teknologi Sepuluh Nopember Indonesia. The 3rd International Workshop on UI GreenMetric. Istanbul (2017)

3. Wahyudi, Firmansyah, Z., Suntoyo, and Tatas. Study on the Distribution of Seawater Influence to the Coastal Groundwater in Eastern Surabaya Coastal Area. Prosiding Seminar Teori dan Aplikasi Teknologi Kelautan "SENTA”, ISSN 1412-2332, Fakultas Teknologi Kelautan, ITS, Surabaya (2012).

4. Padmanagara, S. Geological of Java and Madura Sheet III East Java. 3rd Ed. Geological Survey of Indonesia (1969).

5. Hamsa, M. Yuwono, Okta Ferriska, The Study of Capacity/Volume of Artificial Lake in ITS Campus at Sukolilo as a Water Reservoir Areas, The $7^{\text {th }}$ International Symposium on Earth-hazard and Disaster Mitigation, Bandung (2017) 